\title{
A COMUNIDADE ÁRABE-MUÇULMANA DE FOZ DO IGUAÇU-PR: DA DIÁSPORA A MULTITERRITORIALIDADE ${ }^{1}$.
}

\section{Denis Ricardo Carloto ${ }^{2}$}

A comunidade árabe-muçulmana da cidade de Foz do Iguaçu - PR, analisada em momentos distintos, mas de maneira integrada é o foco do projeto de pesquisa. $A$ saída dos imigrantes de diversas nacionalidades de seus países de origem, bem como suas permanências nesta cidade e a (re)construção de suas identidades culturais e multiterritorialidade, norteiam a pesquisa, a qual pretende contribuir não só para o entendimento das relações sociais estabelecidas como também aquelas possíveis redes que foram construídas e/ou tecidas por esta comunidade. A cidade de Foz do Iguaçu - PR destaca-se tanto pela sua localização estratégica, uma tríplice fronteira (Brasil, Paraguai e Argentina), quanto pela significativa quantidade de árabe-muçulmanos, atualmente em torno de 12 mil pessoas. Possui também uma das maiores mesquitas da América Latina. No primeiro capítulo as categorias analisadas foram: território, territorialidade e multiterritorialidade, com a contribuição de Antonio Carlos Robert de Moraes, Rogério Haesbaert, Joel Bonnemaison, Sylvio Fausto Gil Filho, juntamente com a análise de poder de Claude Raffestin e Pierre Bourdieu. No segundo capítulo, debate-se sobre os conceitos de diáspora e identidade, no qual estão presentes autores como Stuart Hall e Rogério Haesbaert. O terceiro capítulo está diretamente relacionado aos muçulmanos e a construção do Islã, bem como a genealogia acerca do Islã e sua difusão pelo mundo, desde Mohammad o profeta fundador da religião. Ainda no terceiro capítulo o debate é realizado com os autores Peter Demant, Albert Hourani, Samir El Hayek. O quarto capítulo, em construção, o debate central é a discussão dos árabe-muçulmanos na cidade de Foz do Iguaçu-PR. Nesta etapa utiliza-se entrevistas com membros que se destacam na comunidade, fotos, mapas de fluxo migratório de seus países e cidades de origem e mapas representando a formação de redes desta comunidade.

PALAVRAS-CHAVE: árabes-muçulmanos; diáspora; multiterritorialidade.

\footnotetext{
${ }^{1}$ Orientador: Prof. Dr. Sylvio Fausto Gil Filho

${ }^{2}$ Mestrando em Geografia (UFPR) - e-mail: denisgeografia@yahoo.com.br
} 